\title{
Amadeus
} International Multidisciplinary Journal ISSN 2525-8281

\section{Considerations on Refugee Women in Brazil}

Elysyana Barros Moreira ${ }^{l}$, Jucier Gonçalves Júnior ${ }^{2}$, André Luis Sant'Anna ${ }^{3}$; Antônio Marlos Duarte de $\mathrm{Melo}^{4}$;

Athena de Albuquerque Farias $^{5}$,

Bárbara Maria Moreira Dante Santaguida ${ }^{6}$, Gisanne de Oliveira Marinho ${ }^{7}$

\begin{abstract}
Throughout history, women have been facing several situations of disregard for basic human rights. In times where, entire populations are forced to leave their homes and countries to achieve protection and a minimum condition for survival, as in the case of armed conflicts and political crises, gender relations become even more evident, as women are easy targets of physical and psychological aggression. In these times of greater scarcity of basic resources, they are responsible for caring for the most vulnerable families, the elderly and children. The countries of origin of the refugees - Syria, Iraq, Venezuela, among others - also face problems like inequality and patriarchalism. Refugees are sometimes subjected to sexual violence and, to protect themselves, are also forced to marry as children, for instance. These women and girls are not generally seen as human beings but as objects of exchange and weapons of war. It is necessary for international authorities to guarantee protection, shelter and care for refugee women without being required in return for such needed assistance.
\end{abstract}

Keywords: Refugee women, Sexual violence, Human rights.

\footnotetext{
${ }^{1}$ Graduation in Physiotherapy by the Union of Higher Education of Campina Grande. Graduated in Medicine at the Federal University of Cariri - UFCA. Student coordinator of the Cariri Family and Community Medicine Program.

${ }^{2}$ Graduation in Medicine by the Federal University of Cariri - UFCA. Resident in Internal Medicine of Santa Casa de Misericórdia of Fortaleza, Brazil. Contact: juciergjunior@ hotmail.com;

${ }^{3}$ Graduated in Medicine at the University Gama Filho - RJ. Residency in Orthopedics and Traumatology at Hospital

Municipal Barata Ribeiro - RJ. Contact: euamoortopedia@gmail.com;

${ }^{4}$ Graduated in Medicine at the Faculy Medicine Estácio de Juazeiro do Norte, Brasil. Medical Practitioner of the City Hall of Custodia, Brasil. Contact: marlos_duarte@outlook.com;

${ }^{5}$ Lawyer graduated from Centro Universitário dos Guararapes - UNIFG. Specialist in Procedural Labor Law by Faculdades Integradas de Cruzeiro. Master Student in Sustainable Development at the Università degli Studi di Milano. Contact: athena.farias@gmail.com;

${ }^{6}$ Graduation in Law from the Regional University of Cariri - URCA. Master Student in Sustainable Development at the Università degli Studi di Milano. Contact: barbara.santaguida@gmail.com;

${ }^{7}$ Graduation in Law by the Fluminense Federal University - UFF. Master Student in Administrative Justice at the Fluminense Federal University. Contact: gisannemarinho@gmail.com.
} 


\section{Introduction}

By definition, a refugee is a person who leaves his or her country of origin or habitual residence because of a well-founded fear of persecution, whether due to ethnicity, religion, nationality, social group or political opinion; or even because of the grave and widespread violation of human rights, and therefore unable or unwilling to return to its place of origin ${ }^{1}$.

In recent years, about 68.5 million people around the world have been forced to leave their homes ${ }^{2}$. The crisis in Syria is one of the biggest responsible for these numbers. Syrian refugees exceed 4 million. It is not only war that motivates people to flee their countries of origin pursuing better living conditions. Venezuela, for example, faces the biggest political and economic crisis in its history, and by 2017, it ranked fourth in the list of countries where the largest number of new requests for refuge in the world comes out - and the first, if only Latin America was considered - with 111.6 thousand requests for refuge ${ }^{3 ;}$.

In general, men and women are represented almost equally in the refugee population, with 21.3 million men and 21 million women ${ }^{5}$. When considering the countries and regions individually, it can be observed that the demographic characteristics of the refugee populations varied considerably. Bosnia and Herzegovina had the highest proportion of refugee women (58\%), followed by Serbia and Kosovo (56\%), Indonesia (25\%), Ukraine $(30 \%)$, Angola (31\%) and the Republic of Korea (32\%). In Europe, 39\% of the refugee population were women, and 51\% in Africa. Brazil has recognized, by the end of 2017, 10.145 refugees of different nationalities. Of these, only 5.134 continue to reside in the national territory, with women accounting for $30 \%$ of this total ${ }^{2 ; 6}$.

\section{A Strife Position}

Although responsible for a large part of the total refugee population, women are, in general, under-represented in the news or media and literature on the subject. It is known that women and men have different access to networks and experience the relations in different ways in the countries of origin and host countries ${ }^{7}$. To be born a woman in many countries is not an easy task. Being a woman who runs away from your country, leaving behind your dreams, your past and sometimes even your family is even more difficult. Women and men 
face catastrophe scenarios in different ways and war is responsible for amplifying gender inequalities.

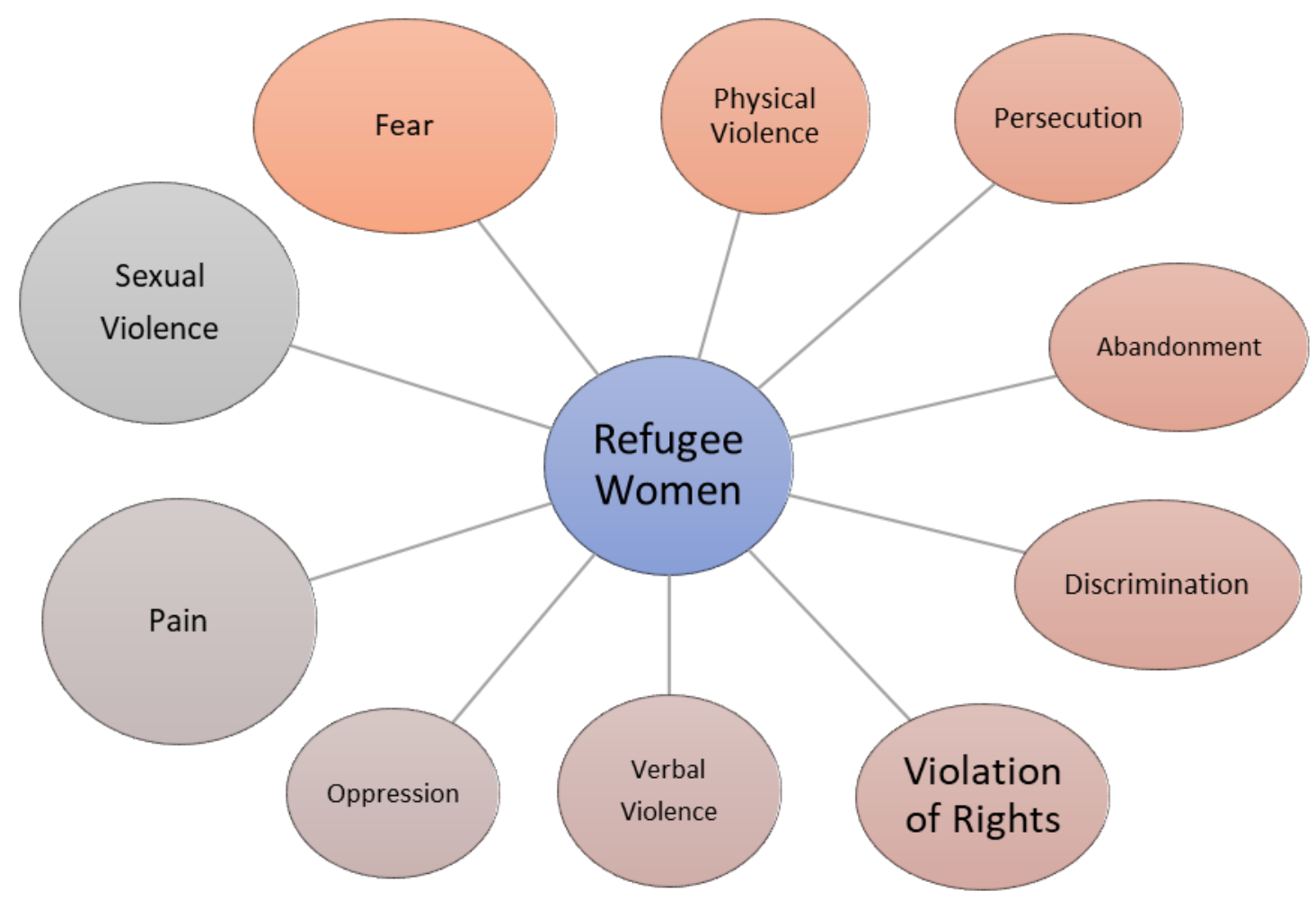

Source: Luis, Silva, Auer \& Albuquerque (2017).

Many of these women have experienced extreme violence and human rights violations not only in their country of origin, but also in refugee camps and host countries, including the murder and disappearance of their family members, sexual and gender-based violence and restricted access to food, water and electricity. In some refugee reception centers in the Greek islands, for instance, refugee women had reported sexual harassment and violence. Attempts to identify offenders and to assist these women are hampered by their reluctance to report attacks due to discrimination, stigma and retaliation, despair and lack of confidence in reporting, including to the UNHCR mental health service ${ }^{8}$. They are afraid because they take care of children and the elderly, which in times of political crisis and armed conflict, can limit their ability to react and increase the need for resources in times of scarcity ${ }^{9} ; 10 ; 11$. 
Their voices illustrate experiences of belonging and displacement. Refugees experience the displacement of plural forms, women face suffering when migrating and the pain of, not often, having news of their loved ones and leaving their homes behind. Augustine Mwamba Feza well exemplifies this painful process: "If they kidnapped your 6-year-old daughter, how could you be in peace with that?" The pain of these women for having lost their children is tremendous 7.8 .

In the long journey of searching for security, they suffer from the indifference of national and international official institutions, with persecution and, not infrequently, sexual abuse and the consequent stigmatization of their refugee status. For women, armed conflict represents a much larger risk, since in many cases rape has been used as a weapon of war ${ }^{13}$.

In international law, there is a perceive inability to recognize that women face specific problems because of their gender and are more vulnerable than men. Since the Refugee Convention does not accept that gender-based violence can be a decisive factor in the search for refuge, much less that refugee women experience much discrimination and violence during their search for shelter. The policies of recipient countries do not adequately integrate into the gender dimension; the different forms of violence faced by women at all stages of their journey in search for security and peace are not taken into account ${ }^{10 ; 11}$.

Despite the efforts to combat violence against refugee women and girls, there is still a long way to go, even in the process of social acceptance of these populations. It is noted that, in countries hosting refugee women, the instruments for the protection of women are insufficient to guarantee their human rights, the situation is even worse for the refugees ${ }^{12}$. Psychological violence, which begins with the oppression and persecution suffered in the country of origin due to gender; the double degree of victimization as a woman and refugee increases the position of vulnerability ${ }^{13}$.

Another problem is the enlarge in the number of child and forced marriages among the refugee population, they are a way to guarantee some protection to young women, perpetuating the idea of woman-ownership. Domestic violence tends to multiply in situations of stress since sometimes, the men in the family discharge their frustrations, fears and disabilities to the women, especially in patriarchal societies. These women are raped by their partners, by the other men housed in the refugee camps and also by those who are offering humanitarian aid from local and international entities ${ }^{11}$. 
Although UN agencies and charities say they do not tolerate any type of violence, in South Syria, for instance, food and rides are offered in exchange for sex. Cases of sexual exploitation are so recurrent that some Syrian women are refusing to go to the centers for distributing supplies. Some organizations turn a blind eye to cases of sexual abuse and exploitation because the only way to bring aid to the most dangerous areas of Syria is through local and third-party authorities. Women without a male protector are more vulnerable to sexual exploitation ${ }^{14}$.

Lack of appropriate health information and the low use of contraceptives is another obstacle, refugee women have higher unplanned pregnancy rates compared to women in host countries. It brings significant consequences on the physical, psychological, social, and wellbeing of women and their families. Specific cultural factors, combined with patriarchal family structures, may present barriers to get access to health services regarding sex issues in a postmigration field. The discourse of conjugal sexual duty leads women to be submissive to the sexual needs of their partners, or to endure marital rape, resulting in significant levels of distress.

\section{Final Considerations}

The establishment of the sexual and reproductive rights of refugee women requires a combination of improvements and systemic services, including recognition of the specific needs of women refugees and the production of health promotion strategies that respect the culture of these women ${ }^{15 ; 16}$.

The literature ${ }^{9 ; 17}$ points out that among refugee women, mental health levels are low, this is due to social factors such as the weight of being wives, mothers and caregivers and to the stress that of the trauma of fleeing from their home country. On the other hand, not being married is also associated with poorer mental health, because the loss of the partner or the burden of being the primary caregiver in the home aggravates the problems. Single mothers or widows may additionally suffer the effects of domestic and sexual violence.

It is necessary, then, to ask: Where are the voices of the women in the organization of intervention responses? In the face of the dangers faced by these women and the lack of representation in the countries that shelter them, an intervention must be seen in the medium 
and long term for the autonomy in their own dignity, the approach requires an exchange in a relation on how equality is being displayed in our current society ${ }^{10}$.

\section{References}

1. UNHCR. Global Trends, Forced Displacement 2016 (UNHCR, 19 de junho de 2017) Disponível em <http://www.unhcr.org/statistics/unhcrstats/5943e8a34/global-trendsforceddisplacement-2016.html $>$. Acesso em: agosto de 2018.

2. ACNUR. Dados sobre Refúgio. ACNUR Brasil, 19 de junho de 2018. Disponível em: $<$ http://www.acnur.org/portugues/dados-sobre-refugio/>.

3. BBC. Fuga de venezuelanos faz país se equiparar ao Iraque em pedidos de refúgio no mundo. BBC Brasil, 23 de junho de 2018. Disponível em: <https://www.bbc.com/portuguese/internacional-44548164>. Acesso em: agosto de 2018.

4. Brasil. Brasil garante assistência a imigrantes venezuelanos sem prejuízo a brasileiros. publicado: 21/06/2018. Disponível em: <http://www.brasil.gov.br/editoria/cidadania-einclusao/2018/06/brasil-garante-assistencia-a-imigrantes-venezuelanos-sem-impactos-abrasileiros>. Acesso em: agosto de 2018.

5. Ventura D, Araújo N. Revista Internacional de Direitos Humanos. Infográficos Migrações e Direitos Humanos. SUR 23, v.12, n.22, 131-139, 2016. Disponível em: <http://sur.conectas.org/infograficos-migracao/>. Acesso em: setembro 2018.

6. UNHCR. Global Trends, Forced Displacement 2017. Disponível em <http://www.acnur.org/stats/globaltrends/5b2956a04/tendencias-globalesdesplazamiento-forzado-en-2017.html> . Acesso em: agosto de 2018.

7. Ozkaleli, U. Displaced selves, dislocated emotions and transforming identities: Syrian refugee women reinventing selves. Women's Studies International Forum 70 (2018) 1723. https://doi.org/10.1016/j.wsif.2018.07.010.

8. Onubr. ONU: mulheres e crianças sofrem violência sexual em centros de refugiados na Grécia. Publicado em 09/02/2018. . Disponível em <https://nacoesunidas.org/onumulheres-e-criancas-sofrem-violencia-sexual-em-centros-de-refugiados-na-grecia/> Acesso em: agosto de 2018.

9. Antunes JAPJ. Refugiados e saúde mental-acolher, compreender e tratar. Psicologia, saúde \& doenças, 2017, 18(1), 115-130. ISSN - 2182-8407. DOI: http://dx.doi.org/10.15309/17psd180110. www.sp-ps.pt 115. 
10. Luis, Alexandra Alves; SILVA, Alexandra; AUER, Christine e ALBUQUERQUE, Rosana. Mulheres refugiadas em trânsito entre discriminações múltiplas: Uma síntese das vozes. Faces de Eva. Estudos sobre a Mulher [online]. 2017, n.37, pp.127-132. ISSN 0874-6885.

11. Esquerda Online. Mulheres refugiadas. Publicado em: 21 Fevereiro, 2018. Disponível em: < https://esquerdaonline.com.br/2018/02/21/mulheres-refugiadas/>.

12. Onubr. Mães de crianças desaparecidas quebram silêncio na República Democrática do Congo. ONUBR. Publicado em 10/07/2018. Disponível em: < https://nacoesunidas.org/maes-de-criancas-desaparecidas-quebram-silencio-na-republicademocratica-do-congo/>.

13. Schwinn As; Costa MMM. Mulheres refugiadas e vulnerabilidade: a dimensão da violência de gênero em situações de refúgio e as estratégias do ACNUR no combate a essa violência. Revista Signos, Lajeado, ano 37, n. 2, 2016. ISSN 1983-0378 DOI: http://dx.doi.org/10.22410/issn.1983-0378.v37i2a2016.1100.

http://www.univates.br/revistas.

14. Landale J; O'dowd V. 'Usadas, abusadas e violadas': as mulheres exploradas na Síria em troca de ajuda humanitária. BBC News. 27 fevereiro 2018. Disponível em: < https://www.bbc.com/portuguese/internacional-43197931 >. Acesso em: agosto de 2018.

15. Mengesha Zb, Perz J, Dune T, Ussher J. Refugee and migrant women's engagement with sexual and reproductive health care in Australia: A socio-ecological analysis of health care professional perspectives. Plos one. https://doi.org/10.1371/journal.pone. 0181421 July 20, 2017.

16. Ussher Jm; Perz J; Metusela C; Hawkey Aj; Morrow M; Narchal R; Estoesta J. Negotiating Discourses of Shame, Secrecy, and Silence: Migrant and Refugee Women's Experiences of Sexual Embodiment. Arch Sex Behav (2017) 46:1901-1921. DOI 10.1007/s10508-016-0898-9.

17. Higgins-Steele A; Lai D, Chikvaidze P; Yousufi K; Anwari Z; Richard Peeperkorn R; Edmond K. Humanitarian and primary healthcare needs of refugee women and children in Afghanistan. Higgins-Steele et al. BMC Medicine (2017) 15:196. DOI 10.1186/s12916-017-0961-y.

\section{How to cite this article (APA format):}

Moreira, Elysyana Barros; Gonçalves Júnior, Jucier; Sant'Anna, André Luis; Melo, Antônio Marlos Duarte de; Farias, Athena de Albuquerque; Santaguida, Bárbara Maria Moreira Dante; Marinho, Gisanne de Oliveira. (2018). Considerations on Refugee Women in Brazil. Am. In. Mult. J., Oct. (5) 3, 28-34.

Received: 07/30/2018.

Accepted: 08/10/2018. 